\title{
Introduction
}





\section{The Technical Dimension of Action}

\section{Basic Orientation: Approaching the Composition of Action}

One of the remarkable features of our contemporary international scene is the number of intense social movements. From Caracas to Bagdad, from Hong Kong to Paris, the instances are legion. Protesters adopt strategies that range from peaceful protest to acts of violence, justifying their action with an array of arguments, communicating their grievances through different channels and attempting to bind isolated individuals into reliable groups supporting their cause. All of them act within existing social and political contexts: more or less firmly established institutions, varying economic conditions, more or less ruthless states, available forms of justification for police or military intervention, etc. In short, in each case, a dense and complex cocktail of disparate and mutating elements plays out in a rich diversity of events.

Impressive (and sometimes frightening) as the spread and intensity of these diverse events may be, at their core, there are a number of persistent features of social upheavals and, indeed, of human action in general. Four of these features are the object studied in this book. First, in each case, different individual, organizational or institutional agents combine actional capabilities with tools, institutions, infrastructure, etc. by means of which they act. In this volume, I refer to this combination of capabilities and means as the "technical dimension of action" or simply as the "technicity of action". Second, the deployment of capabilities and means is consistently permeated by ethical aspirations and hesitancies. Third, the myriad of strategies and forms of protest events vividly illustrates this task of combining capabilities with means and its impregnation by ethics; yet, one finds it in all domains of human action: in the workplace, in different forms of education, in commerce, and even in religious practices and in domestic interaction. Fourth, the current global spread of these events provides sufficient material to convince us that the need to combine capabilities with means, and these together with ethics, is typical of human life in general, and not just a regional or culturally specific phenomenon. ${ }^{1}$

In this book I attempt to think through these four basic components of social interaction. How is this to be done? First, careful attention is paid to the fact that action has meaning for agents. Let us call this the interpretative or hermeneutic concern of this study. Second, equally careful attention is given to the complex-

1 The point is precisely the generality of this feature, not defining what human is, nor excluding the possibility that this remark may also be valid in respect of animals.

Ә OpenAccess. ( 2021 Ernst Wolff, published by De Gruyter. (cc) BY-NC-ND This work is licensed under the Creative Commons Attribution-NonCommercial-NoDerivatives 4.0 License. 
ities of action as interaction in social contexts. Let us call this the social theoret$i c^{2}$ concern of this study. These two orienting concerns should already make it plain that this study aims neither at a philosophy of technology, nor at an exploration of the material background of action or a theory of culture - although the insights developed here should be relevant to these fields too. The aim of the study is to develop in outline an interpretative theory of technicity as an aspect of human action. I know of no equivalent endeavour in the scholarly literature to date. ${ }^{3}$

This initial indication of the orientation of the book calls for three clarifications, which is the task of this Introduction.

My primary strategy is to integrate the hermeneutic and social theoretic concerns by drawing the maximum of insights from an author in whose work they are coordinated: Paul Ricœur. It is this fine coordination, buttressed by the strength of his broader philosophy, that justifies the central attention to him in this book. The best way to clarify my choice of Ricœur as my main ally in hermeneutics is by providing a brief survey of the relation of his hermeneutics to

2 I use the term "social theory" simply to designate all the different contributions, independent of the disciplinary specificity of their authors. The point is not a polemic opposing philosophy to theory.

3 To be precise, there is a wide array of literature with which I can find a meaningful connection and from which I can draw insights for my project. After all, the technical dimension of action is a basic given of human existence. Moreover, drawing from such exchanges is a structuring feature of this book as a whole. Still, I do not know of any work that is dedicated to the technicity of action across the entire breadth of human action and interaction, and that is written from an interpretive or hermeneutic point of view. A review of recent overviews of social theory confirm this, see Philippe Corcuff, Théories sociologiques contemporaines: France, 1980-2020 (Malakoff: Armand Colin, 2019), Claudio E. Benzecry, Monika Krause, and Isaac Reed, eds., Social Theory Now (Chicago, IL, and London: University of Chicago Press, 2017), Seth Abrutyn, ed., Handbook of Contemporary Sociological Theory (Cham: Springer, 2016), Patrick Baert and Filipe Carreira Da Silva, Social Theory in the Twentieth Century and Beyond, 2nd ed. (Cambridge: Polity Press, 2010), Georg Kneer and Markus Schroer, eds., Handbuch Soziologische Theorien (Wiesbaden: Springer VS, 2009), Gerard Delanty, Handbook of Contemporary European Social Theory (London: Routledge, 2006).

There are also a number of works which I recognize as displaying some proximity to my project - e.g. Johannes Robeck, Technologische Urteilskraft. Zu einer Ethik technischen Handelns (Frankfurt am Main: Suhrkamp, 1993), Christoph Hubig, Die Kunst des Möglichen (Bielefeld: Transcript, three volumes, 2006, 2007 and 2015) and Werner Rammert, Technik - Handeln - Wissen: Zu einer pragmatistischen Technik- und Sozialtheorie, 2nd ed. (Wiesbaden: Springer VS, 2016). However, since these volumes are not concerned with the hermeneutic approach that I set out to develop, and since they are aimed more specifically at application in various fields of technology (in contrast to the more ethical and political orientation of my last Chapters), discussing them falls beyond the scope of this book. 
social theory (§2) and the presence of the problematic of the technicity of action in his (early) philosophy (§3). However, I do not accord Ricœur dogmatic authority, nor is this a purely exegetical study. This is avoided by the specific design of the chapters - which is my next point.

In each chapter insights are gathered from Ricœur's work and submitted to critique through dialogue with other theorists and intellectuals from a host of different social scientific backgrounds and disciplines: Régis Debray, Norbert Elias, Anthony Giddens, Luc Boltanski, Nelson Mandela, Okolo Okonda, Karl von Holdt and others - each chosen for the specific questions addressed in that chapter. My own theoretical developments emerge from these confrontations. The best way to clarify what this entails is by an overview of the chapters and the relations between them. This is done in two steps, for Part $1(\S 4)$ and Part 2 (§5) of the book, respectively.

Finally, I comment on the "Intermediary reflexion" (which links the two parts of the book) and on the Conclusion, both of which serve to qualify the nature and ambition of this project (§6).

\section{Ricœur and Social Theory}

One of the most formative readings of my academic life thus far has been Joas and Knöbl's Social Theory: Twenty Introductory Lectures. Their masterly panorama of post-World War II social theory covers a wide variety of authors and movements of Western social theory in a compelling argumentative and historical presentation. Chapter XVI is dedicated to three French authors, collectively typified as "non-structuralist": Castoriadis, Touraine and Ricœur. ${ }^{4}$ The significant position accorded to Paul Ricœur $(1913-2005)$ by these two erudite sociologists may have come as a surprise to readers who were acquainted with the reception of Ricœur's philosophy during most of his lifetime. For a long time, his name was mostly associated with a kind of phenomenology, a philosophy that was then somewhat out of sync with mainstream "French theory", and concentrated instead on a hermeneutic turn to symbols, metaphors, narratives and perhaps the capable human. However, what Joas and Knöbl correctly recorded was, on the one hand, the tremendous wealth of social theoretic thought of this French

4 Hans Joas and Wolfgang Knöbl, Lecture XVI: "French anti-structuralists (Cornelius Castoriadis, Alain Touraine and Paul Ricœur)," in Social Theory: Twenty Introductory Lectures (Cambridge: Cambridge University Press, 2009), 401-31. 
philosopher, and on the other, the strongly welcoming reception from theorists in various social sciences that he began to enjoy later in life.

This shift needs some clarification. It is worth recalling that even before his reception in French sociology, Ricœur had cultivated a keen interest in a variety of social sciences throughout his career. Whether in political science, sociology, anthropology, or historiography, one has no difficulty finding the traces of reflection and concentrated discussions with contemporary authors in his work, such as Lévi-Strauss, Weber, Elias, Boltanski and Thévenot, Mannheim, and Geertz. This is no artificial addition, as his entire work can be described as a reflection on human action, ${ }^{5}$ from which the well-known works of hermeneutics are but a long detour. To get an impression of his sustained contribution to social theory, one can enumerate the themes to which Ricœur devotes substantial study: action and fallibility, practical reason and ideology, interpersonal action and institutions, historicity and modernity, justice and recognition - the list is far from exhaustive. ${ }^{6}$ All this work is infused with insights from his hermeneutics, the significance of which for post-World War II philosophy is commonly recognized.

Next, stepping from the philosopher to his social scientific reception, one could indicate several social scientists who made some use of his work in devel-

5 Cf. Paul Ricœur, "Préface," in Maurizio Chiodi, Il cammino della libertà. Fenomenologia, ermeneutica, ontologia della libertà nella ricerca filosofica di Paul Ricœur (Brescia: Morcelliana, 1990), ix-xix, and Paul Ricœur, "Proménade au fil d'un chemin," in Fabrizio Turoldo, Verità del metodo. Indagini su Paul Ricœur (Padua: Il Poligrafo, 2000), 13-20. The anglophone public has been sensitised to this dimension of his work by a volume edited by Cambridge sociologist John Thompson, namely Paul Ricœur, Hermeneutics and the Human Sciences: Essays on Language, Action and Interpretation (Cambridge: Cambridge University Press, 1995).

6 The bulk of this work is contained in Paul Ricœur, L'idéologie et l'utopie (Paris: Seuil, [1986] 1997) / Lectures on Ideology and Utopia (New York, NY: Columbia University Press, 1986), Paul Ricœur, Du texte à l'action. Essais d'herméneutique II (Paris: Seuil, 1986) / From Text to Action: Essays in Hermeneutics II, trans. Kathleen Blamey and John Thompson (London: Athlone, 1991), Paul Ricœur, Soi-même comme un autre (Paris: Seuil, 1990) / Oneself as Another, trans. Kathleen Blamey (Chicago, IL: University of Chicago Press, 1992), Paul Ricœur, Le juste 1 (Paris: Esprit, 1995) / The Just, (Chicago, IL: University of Chicago Press, 2000), Paul Ricœur, Le juste 2 (Paris: Esprit, 2001) / Reflections on the Just, trans. David Pellauer (Chicago, IL: University of Chicago Press, 2007), and finally, Paul Ricœur, Parcours de la reconnaissance (Paris: Gallimard, 2004) / The Course of Recognition, trans. David Pellauer (Cambridge, MA: Harvard University Press, 2005). Parts of the book of interviews, Paul Ricœur, La critique et la conviction. Entretien avec François Azouvi et Marc De Launay (Paris: Calmann-Lévy, 1995) / Critique and Conviction: Conversations with François Azouvi and Marc De Launay. European Perspectives (New York, NY: Columbia University Press, 1998) and to a lesser degree the tome on the philosophy of history, Paul Ricœur, La mémoire, l'histoire, l'oubli (Paris: Seuil, 2000) / Memory, History, Forgetting (Chicago, IL: University of Chicago Press, 2004), should likewise be taken into account here. 
oping their own views - to cite but two random examples: V. Y. Mudimbe in his understanding of the invention of Africa or Clifford Geertz's symbolic anthropology. ${ }^{7}$ Much more significant is the "Ricœur effect" in French social science, already recorded by François Dosse in $1995 .{ }^{8}$ The most significant names to mention in this regard are Luc Boltanski and Laurent Thévenot, the originators of "French pragmatism." 9

A third layer of the relation between Ricœur and social theory is presented by recent scholarship. ${ }^{10}$ Over the last two decades, this scholarship has over-

7 Valentin Yves Mudimbe, The Invention of Africa: Gnosis, Philosophy, and the Order of Knowledge. African Systems of Thought (Bloomington, IN: Indiana University Press, 1988); Arun Micheelsen, “II Don’t Do Systems': An Interview with Clifford Geertz," Method and Theory in the Study of Religion 14, no. 1 (2002): 2-20.

8 François Dosse, L'empire du sens. L'humanisation des sciences humaines (Paris: La Découverte, 1995), see Chapter 14, "Une philosophie de l'agir: Paul Ricœur," 170 -79.

9 Luc Boltanski and Laurent Thévenot. On Justification: Economies of Worth (Princeton, NJ: Princeton University Press, [1991] 2006). Laurent Thévenot's major publication, L'action au pluriel. Sociologie des régimes d'engagement (Paris: La Découverte, 2006) is dedicated to Ricœur. 10 In recent years the number of thematic volumes of journals dedicated to Ricœur have shown an increasing interest in the social and political philosophical aspect of his work, cf. the Journal Phänomenologie 21 (2004), the Journal of French Philosophy 16, nos. 1-2 (2006), the Revue de Metaphysique et de Morale 2 (2006), Cités 1, no. 33 (2008), Philosophiques 41, no. 2 (2014), the Revue des Sciences Philosophiques et Théologiques 99, no. 4 (2015), Chiasmi International 17 (2016). Among the volumes of the Ricœur Studies/Études Ricœuriennes, see for example, 2, no. 1 (2011) (on recognition), 3, no. 1 (2012) (on the social sciences), 4, no. 1 (2013) (on feminism), 6, no. 2 (2015) (on justice), 9, no. 1 (2018) (on ideology and utopia), 9, no. 2 (2018) (on vulnerability), 10, no. 2 (2019) (on practical wisdom).

A similar trend can be seen in collected volumes: cf. some of the essays in Christian Delacroix, François Dosse and Partick Garcia, eds., Paul Ricœur et les sciences humaines (Paris: La Découverte, 2007), David Kaplan, ed., Reading Ricœur (New York, NY: State University of New York Press, 2008), Scott A. Davidson, ed., Ricœur Across the Disciplines (New York, NY: Continuum, 2010) (some chapters in this volume, with its accent on textual disciplines), and almost all of the contributions in Farhang Erfani and Lorenzo Altieri, eds. Paul Ricœur: Honoring and Continuing the Work (Lanham, MD: Lexington Books, 2011). The titles of two new publications are telling: David Lewin and Todd S. Mei, eds., From Ricœur to Action: The Socio-Political Significance of Ricœur's Thinking (London, and New York, NY: Continuum, 2012) and Marcelino Agis Villaverde, Knowledge and Practical Reason: Paul Ricœur's Way of Thinking (Berlin and Zurich: Lit Verlag, 2012). Other relevant texts are Roger Savage, Paul Ricœur in the Age of Hermeneutical Reason: Poetics, Praxis, and Critique. Studies in the Thought of Paul Ricœur (Lanham, MD: Lexington Books, 2015), Annemie Halsema and Fernanda Henriques, eds., Feminist Explorations of Paul Ricœur's Philosophy (Lanham, MD: Lexington Books, 2016), Suzi Adams, ed., Ricœur and Castoriadis in Discussion: On Human Creation, Historical Novelty, and the Social Imaginary. Social Imaginaries (Lanham, MD: Rowman and Littlefield International, 2017), and Stephanie N. Arel 
whelmingly confirmed the significance of the socio-political dimension of his work, which justifies discarding the outdated idea that Ricœur was only interested in matters of textual interpretation which bears no relevance to practical philosophy.

My book is situated in the extension of these three layers of connection between philosophy and social theory. From this perspective, this book aims at making a contribution to both the interpretation of Ricœur's socio-political thought and the development of significant features of it. We will explore why human action is not merely an instrumental concatenation of sub-actions aimed at a preestablished goal, but is rather a much more complex exercise of practical or conscious interpretation and adaptation of courses of action. How action is always informed - that is, guided or impaired - by normative or ethical concerns, hesitations and dispositions, is a second question. At the same time, we will see that the practical situations in which people act do not always allow them simply to realize their normative motives, and in fact, the very means by which they hope to realize them often negatively affect other concerns. A central contention of this book is that we can only gain a proper grasp of the difficult composition of efficiency and normativity in action from a coordination of hermeneutic and social theoretic inputs.

But I must pre-empt the sceptic. As significant as these questions may be, are they not marginal to Ricœur's thought? Surely this is not a theme by

and Dan R. Stiver, eds., Ideology and Utopia in the Twenty-First Century: The Surplus of Meaning in Ricœur's Dialectical Concept (London, and New York, NY: Lexington Books, 2019).

Likewise, one could consider a number of monographs: Bernard Dauenhauer, Paul Ricœur: The Promise and Risk of Politics (Lanham, MD: Rowman and Littlefield, 1998), David Kaplan, Ricœur's Critical Theory (Albany, NY: State University of New York Press, 2003), Johann Michel, Paul Ricœur. Une philosophie de l'agir (Paris: Cerf, 2006), Peter Kemp, Sagesse pratique de Paul Ricœur: Huit études (Paris: Editions du Sandre, 2010), Molly Mann, Ricour, Rawls and Capability Justice: Civic Phronesis and Equality (London, and New York, NY: Continuum, 2012), Pierre-Olivier Monteil, Ricœur politique (Rennes: Presses Universitaires de Rennes, 2013), Inge Künle, Das Selbst und der Andere bei Paul Ricœur und Amartya Sen (Berlin: Lit Verlag, 2014), Michael Sohn, The Good of Recognition: Phenomenology, Ethics, and Religion in the Thought of Levinas and Ricœur (Waco, TX: Baylor University Press, 2014), Maureen Junker-Kenny, Religion and Public Reason: A Comparison of the Positions of John Rawls, Jürgen Habermas and Paul Ricœur (Berlin: De Gruyter, 2014), Jean Greisch, L'herméneutique comme sagesse de l'incertitude (Paris: Le cercle herméneutique éditeur, 2015), Timo Helenius, Ricœur, Culture and Recognition: Hermeneutics of Cultural Subjectivity (Lanham, MD: Lexington Books, 2016), Dries Deweer, Ricœur's Personalist Republicanism. On Personhood and Citizenship (Lanham, MD: Lexington Books, 2017), Geoffrey Dierckxsens, Paul Ricœur's Moral Anthropology: Singularity, Responsibility, and Justice (Lanham, MD: Lexington Books, 2018). 
which to present the reader with a substantial view on Ricœur's social theory? To both objections I would respond: Not at all!

\section{Ethics and Means in Ricœur. A Preliminary Exploration}

Once made aware of it, one cannot help but notice how often and how thoroughly Ricœur grappled with the question of the need and the ambiguity of the means of action as encountered in the heat of the action. ${ }^{11}$ This is a question of efficacy, but the urgency of the "heat" of action is equally informed by agents' ethical investment in what they do. In this book, I explore this dimension of Ricœur's thought by focusing on his later work (roughly from the 1970s to 2005, although the exact demarcation is not important). However, one can introduce the issue with reference to much earlier texts to get an impression of how this dimension of his thinking emerged. ${ }^{12}$ In this way, the contemporary relevance of the question will also become apparent.

\subsection{Efficacy, without Abandoning Ethics}

At the end of the 1940s, Ricœur engaged Merleau-Ponty in a debate about the possible sources for positive change in society. On the one hand, he seemed reluctant unreservedly to accept Merleau-Ponty's version of the recourse to "progressive" violence found in Humanism and Terror. On the other hand, he had had five years in a prisoner-of-war camp to ruminate on the inadequacies of his pre-war pacifism. His response, published as "Non-violent Man and His Presence to History" in 1949, can be schematized in a number of steps. ${ }^{13}$

11 For an encompassing study of Ricœur's views on technology throughout his work, see Ernst Wolff, "Ricœur's Polysemy of Technology and its Reception,” in Interpreting Technology, eds. Mark Coeckelbergh, Wessel Reijers and Alberto Romele (Lanham: Rowman and Littlefield, forthcoming 2021).

12 The interpretation of Ricœur's earlier philosophy is itself a major topic. I have dealt with it on its own in a separate monograph, entitled Lire Ricœur depuis la périphérie. Décolonisation, modernité, herméneutique (forthcoming). Harvesting the insights of Ricœur's earlier work, especially Freedom and nature. The voluntary and the involuntary and Fallible Man, would certainly add valuable material to the argument of the present book, but this will have to be dealt with in a separate study.

13 Paul Ricœur, "L'homme non-violent et sa présence à l'histoire” [1949], Histoire et vérité (Paris: Seuil, 1964), 265-77 / "Non-violent Man and his Presence to History," in History and Truth, trans. Charles A. Kelbley (Evanston, IL: Northwestern University Press, 1965), 223-33. 
As a first step, he sketches a vast anatomy of violence in society: military, political, religious, or economic violence, but also the "violence of law and order", ${ }^{14}$ of poverty, and of exploitation. It is a philosopher's social diagnostic, but it stands for a thorough, realistic study of social complexities and his avoidance of a simplistic view on society as a family, a club or contract-based cooperation. This is essential to Ricœur's lifelong indebtedness to the social sciences: instead of constructing ideal theory in abstraction of social reality, he aspires to philosophise from the thick of it.

The product of this realist approach is his insistence on the problem of efficacy, which forms the next step. Ricœur seeks to understand efficacy, which is bound up with an ethical sensitivity (a "prise de conscience") to the harm of violence. In terms both he and Merleau-Ponty adopt from Koestler, efficacious (and not just theoretical) improvement of society has to be sought by avoiding the extremes of moralist detachment and brutal realism, positions designated by the ideal-typical role of the "yogi" and the "commissar" respectively. Between these extremes, Merleau-Ponty situates the uncertain, but progressive, violence of the "proletarian". Ricœur concurs, writing that "there is a political task and this task is in the thick of history [en pleine pâte dans l'histoire]". ${ }^{15}$ Still, he is worried that, in practice, nothing would prevent the "proletarian" from eventually sliding into the role of the "commissar".

The third step is Ricœur's argument that there is something in human societies that may put a brake on this degeneration of the "proletarian". This social role is named the "prophet", which is distinct from the yogi. ${ }^{16}$ This role stands for the human possibility to produce signs, markers or pointers - reminders - of that which the "proletarian" is fighting for. This is by no means a simple fantasy. Ricœur's prime example is that of Gandhi, although not as an idealized Indian mystic, as Ricœur had his reservations regarding some aspects of the Gandhian doctrine. His point is not that the Gandhi-like "prophet" has to replace his political partner, the "proletarian", but rather that "prophets" can guide "proletarians" by singular, occasional demonstrations critiquing the status quo.

The fourth step - the significant issue I want to highlight - has to do with the exact characterisation of this social role. There can be a real "dialectic of prophetic non-violence and progressivist violence," 17 but only if non-violence can be efficient ${ }^{18}$. This is what qualifies Gandhi as a "prophet": "far from the non-vio-

14 Ricœur, Histoire et vérité, 269 / History and Truth, 226.

15 Ricœur, Histoire et vérité, 276 / History and Truth, 232 (translation modified).

16 Ricœur, Histoire et vérité, 271, 273 / History and Truth, 228, 230.

17 Ricœur, Histoire et vérité, 276 / History and Truth, 232.

18 Cf. Ricœur, Histoire et vérité, 271 / History and Truth, 228. 
lent person banishing these goals from history and deserting the scheme of means, leaving them to their impurity, the non-violent attempts to bring them together in an action which is at one and the same time a spirituality and a technique [une spiritualité et une technique]". ${ }^{19}$ It is, as Ricœur emphatically repeats, a strategy which combines the generating symbols expressive of an ethical prise de conscience of difficult situations on the one hand and, on the other, a technology ("technique") of resistance and of disobedience. ${ }^{20}$ Moreover, the "prophet” is never to go it alone: this role needs its dialectical counterpart in the continuous, political action of the "proletarian".

For our current purposes, the issue is not whether we accept Ricœur's mobilisation of four ideal typical social roles or his enthusiasm for Gandhi. The point is rather that Ricœur's whole effort consists of thinking through the coordination of major, conflicting dimensions of action - violence, withdrawal, collaboration, ethical aims, strategy - in the course of action. We can measure the significance of Ricœur's insistence on the problematic coordination of ethics (or symbols) and technics (or efficacy) by glancing back at the text by Merleau-Ponty to which he responds. Merleau-Ponty describes exactly this difficult coordination as insurmountably part of the human condition. ${ }^{21}$ One person who understood this dilemma, Merleau-Ponty claimed, was Max Weber, notably in his opposition of an ethics of conviction centred on pursuing pre-established principles, and an ethics of responsibility, which, in full knowledge of the unforeseeable circumstances of actions, engages with the means at one's disposal. Those who operate under an ethics of conviction are the naïve idealists, those who operate under an ethics of responsibility are the realists. ${ }^{22}$ Ricœur's article on violence and non-violence is an attempt to acknowledge the full significance of the uncertainty involved in action, while recognizing the unavoidability of using means, even powerful and lethal ones, in pursuit of efficient interventions in reality. At the same time, he is willing neither to abdicate ethical considerations, nor to abandon

19 Ricœur, Histoire et vérité, 273 / History and Truth, 230 (translation modified).

20 Cf. Ricœur, Histoire et vérité, 274 / History and Truth, 231.

21 Maurice Merleau-Ponty, Humanisme et terreur: Essai sur le problème communiste (Paris: Gallimard, 1947), 30 / Maurice Merleau-Ponty, Humanism and Terror: The Communist Problem, trans. John O’Neill (New Brunswick, NJ: Transaction, 2000), xxxviii.

22 This is Merleau-Ponty's reading. I differ somewhat from this reading, cf. Ernst Wolff, Political Responsibility for a Globalised World. After Levinas' Humanism (Bielefeld: Transcript Verlag, 2011), 189-203, summarised in Ernst Wolff, "Responsibility to Struggle - Responsibility for Peace: Course of Recognition and a Recurrent Pattern in Ricœur's Political Thought,” Philosophy \& Social Criticism 41, no. 8 (2015): 771-90, here 773-75, 189-203. See also the contemporary analysis and appraisal in Etienne de Villiers, Revisiting Max Weber's Ethic of Responsibility (Tübingen: Mohr Siebeck, 2018). 
them to moralists. The question of coordinating a "spirituality" and a "technology" is the question of coordinating human capabilities and means with normative considerations. In the decades that followed, Ricœur worked on coordinating the affirmation of an uncertain human context, and the quest for efficient interventions in it, with the critical negation of mere acceptance of the status quo.

\subsection{An Ethics of Limited Violence}

This position can be seen again in a quite different argumentative context: Ricœur's seminal essay on political philosophy, "The Political Paradox". ${ }^{23}$ The article is written as a reflection on a particular historical event, namely, the Russian suppression of the Hungarian uprising in 1956. The argument, however, is established from a purely philosophical basis with a view on what Ricœur considers the most lasting general features of politics. We are only able to understand the violence of Budapest, or any other political brutality, he claims, if we understand what is specific about politics or, as he says, the political (le politique). He attempts to grasp this specificity with the help of the history of political philosophy. Everything depends on how one understands the relation between a number of basic views.

To begin with, one must acknowledge the truth of a tradition stretching from Aristotle to Rousseau and Hegel, which sees an essential component of our humanization in political life, that is, life as a citizen of a state. This is a peculiar truth; it is not simply a given, but rather a valid aspiration (aim or "visée"24). Each critique of an abuse of political power silently presupposes the "reality of this ideality". ${ }^{25}$

However, it is not very helpful merely to affirm this point without examining how to realize this virtuous work. Therefore, one also has to grant the validity of two quite different views on the state. First, Ricœur affirms with Eric Weil that the state is the expression of the will of the people. This is not meant to be a categorical approval of what states do, rather, it simply means that the state is necessary to bind the plurality of citizens together in order to enact what it is they want to do. States allow people to achieve things that are unimaginable in a condition of statelessness. However, following this line of thought, Ricœur encounters the validity of Weber's instrumentalist view of the State, namely as the entity

23 Paul Ricœur, “Le paradoxe politique” [1957], Histoire et vérité, 294-321 / “The Political Paradox," History and Truth, 247-70.

24 Cf. Ricœur, Histoire et vérité, 297 / History and Truth, 249.

25 Ricœur, Histoire et vérité, 300 / History and Truth, 252. 
that successfully lays claim to a monopoly on the legitimate use of violence within a given territory. For Weber, it is nonsense to speak about the aim of a State. All we know is that it is a powerful tool, and that having a vocation for politics implies a willingness to take the powerful tools of the State into one's hands.

In this combination, Weil theorizes the relay from popular will to the powers of the State, while Weber contributes the dimension of the state as an instrument under conditions of uncertainty. Together, this accounts for political action as "rational organization" 26 and for its ability to take and execute decisions. The junction of Weil-Weber with the aforementioned tradition of flourishing through political life gives us an affirmative view on political matters, in the sense that it emphasises what can or should be realized.

But there are also a host of negative discourses on politics and the state. Authors expose the abuses of power, the hypocrisy of the state, rulers that parade as champions of the people while facilitating their exploitation, etc. This is the invaluable contribution of thinkers such as Marx or Lenin. Whatever the myriad of dissenting arguments may be, they all draw their force from presupposing the validity of people's aspiration toward a better life through political coexistence (on which the argument is premised from the beginning).

Far from a position of non-committal or a random conflation, Ricœur attempts to coordinate these positions into something like a lasting grammar of political power. This grammar of political power drives politics again and again into a series of interrelated paradoxes. I identify three in this text: ${ }^{27}$

- The means and power to give effect (and efficacy) to the collective will is a power which can turn against the citizenry.

- Hence, a specifically political evil emerges from the possibility of a specifically political good. Political evil is a perversion of political rationality itself.

- For the sake of avoiding political evil, the same liberty of the citizenry that founds states as powerful entities for the realization of liberty has to limit that same power of States.

With these three paradoxes, we are already at the heart of the point I wish to make about this key text of Ricœur's. For Ricœur, a paradox ${ }^{28}$ is an opposition or contradiction that cannot be solved in theory, but that must instead be

26 "[O]rganisation raisonnable," Ricœur, Histoire et vérité, 303 / History and Truth, 255.

27 For a detailed discussion of the "political paradox" throughout Ricœur's work, see Monteil, Ricœur politique, 27-68.

28 Ricœur's own definition, albeit from a much later essay, is that a paradox is "a situation in which two contrary theses equally oppose being refuted and, as a result, require being preserved or abandoned together," Ricœur, Le juste 2, 27, 86 / Reflections on the Just, 19, 73. 
dealt with in practice. This is of cardinal importance, as it shows how his initial political-historical argument drives us directly into the arms of the problems of action. The paradox arises from both an insistence on the difficulty and uncertainty of action and an affirmation of the urgency to deal with it (because something is at stake in it). Ricœur comments on these complexities in the frame of his reflection on politics. If the exposition above is correct, then, Ricœur argues, the central problem of democracy is that of the people controlling the State. Or, as he says explicitly, "to devise institutional techniques especially designed to render possible the exercise of power and render its abuse impossible." ${ }^{29}$ His point is neither technocratic nor instrumentalist. Rather, it is that abstract moralization is worth nothing: if we are serious about action, we must consider the means by which to give effect to our concerns. Among these institutional "techniques of controlling the State", ${ }^{30}$ what Ricœur has in mind are the free activity of trade-unions, the independence of the judiciary, the availability of education, free circulation of information, and generally submitting the State to control through democratic debate. It would be missing the point to see here only the advocacy of political liberties. Ricœur does not dream of a minimal State, since, in the very specific sense described above, he views the State as something good. People need an efficient State. But there is no escaping the political paradox, and hence, Ricœur advocates an "ethic of limited violence", ${ }^{31}$ that is, striving to let normative considerations weigh in on the means chosen for action, in full knowledge of how dangerous they may be. Nor does he dream of reducing the State to an apparatus for distributing goods and tasks - the State is devoid of meaning without the aspiration of people to which it is to give effect.

In short, prompted by dramatic political events, the philosopher passes in review insights gathered from the history of his discipline, only to return again through this detour to the very complexity of action. At the heart of his problem are the questions that concern this book: the tension between individual and collective action, the technical dimension of action, the coordination of ethical considerations and the desire for efficacy, and realism about the difficulty of finding an appropriate course of action in a given context.

29 My emphasis, Ricœur, Histoire et vérité, 311, similarly 314-15 / History and Truth, 261-2, similarly $264-65$.

30 Ricœur, Histoire et vérité, 321 / History and Truth, 270.

31 Ricœur, Histoire et vérité, 312 / History and Truth, 262. 


\subsection{With and Against Ricœur}

It is this problem complex (which, as I have just demonstrated, emerges from the heart of Ricœur's early socio-political thought) that I do not see explored in the scholarship, ${ }^{32}$ and that is precisely the lacuna that I hope to fill. Since Ricœur's early work on the phenomenology of the will, it is evident that he was bent on understanding action. The two early texts we have considered briefly, "Non-violent Man..." and "The Political Paradox" add a number of details to this wellknown fact. They give us a view on the kind of problems which continuously nourished Ricœur's abiding fascination with action. No matter how far the historical or philosophical detour may go, this reflection aims at the difficulties of action in a context. Furthermore, they also confirm my claim that the coordination of capabilities and means (the "technicity" of action) and the difficult coordination of these dimensions of action with ethical concerns have, from early on, formed part of Ricœur's socio-political thought. Finally, the place of ethics in action is demarcated and the difficult adjustments between ethics and the context which allows agents to realize it are thought through. However, the question of the ultimate foundation, or at least justification, of ethics is not addressed in these texts. For this reason, these studies point rather to an action theoretical reflection than to a fundamental "moral philosophy".

Seen from this perspective, Ricœur will be my ally throughout this book. However, my aim still remains to make an independent contribution. For this reason, I have not hesitated to express my disagreement with Ricœur (as I do with other scholars) and to develop additions or improvements where I considered them necessary. Since this is an equally important part of the project, let us look at it more closely.

\section{A Contribution to Interpretive Social Theory}

Although I do not claim to give an exhaustive survey of Ricœur's contribution to social theory, by working on the questions outlined above, it is possible to offer a more systematic exploration of the central tenets of this aspect of his work than, for instance, Joas and Knöbl could do in Social Theory: Twenty Introductory Lec-

32 Of course, texts abound in which the question of the difficult compromise between ethics and morality is thematized, following Ricœur's own examination of prudence in action. But even there, the question of actional efficiency is largely neglected. 
tures to which I referred above. ${ }^{33}$ In order to keep the scope of the study manageable, I do not discuss his earlier philosophy of the will, ${ }^{34}$ but focus instead on his later practical philosophy and the hermeneutics of human capabilities. Furthermore, I diverge quite sharply from Joas and Knöbl by incorporating authors from outside of the West as essential conversational partners in this book. ${ }^{35}$ In a book where universal anthropological claims are being made, such openness is indispensable, and, regardless of this point, the reader will see that this is done in service of answering my central questions (more about this below). Furthermore, while I gratefully draw from Ricœur's hermeneutics and strive to do justice to his work, this study also aims to do more than add to Ricœur scholarship in three respects.

First, each chapter contains expositions of his work, but proceeds by extending his arguments, filling in lacunae, exploring unexamined possibilities or contradicting his views. ${ }^{36}$ This is done both by critically commenting on his work and by engaging with social scientific theories. The latter interlocutors have been chosen in each chapter specifically to help me advance in one or another problem, relative to the broader project of understanding the technicity of action. A short overview of what this entails is given in the chapter summaries below. The outcome is a study that has definite Ricœurian traits, but is also clearly an independent contribution.

Second, although I have demonstrated above that the overall theme of this book is not foreign to Ricœur, it would have been a vain endeavour to look for a developed hermeneutics of the technicity of action in his work. This thematic de-

33 Johann Michel, Paul Ricœur. Une philosophie de l'agir (Paris: Cerf, 2006) gives an interpretation of Ricœur's major works as they relate to action.

34 On this work, see Scott A. Davidson, ed., A Companion to Ricœur's Freedom and Nature (Lanham, MD: Lexington Books, 2018) and Jean Greisch, L'herméneutique comme sagesse de l'incertitude (Paris: Le cercle herméneutique éditeur, 2015), 59-116.

35 However, both of them have taken these questions seriously in other publications. See, for instance, Wolfgang Knöbl, Die Kontingenz der Moderne. Wege in Europa, Asien und Amerika (Frankfurt am Main: Campus Verlag, 2007) and Hans Joas, Sind die Menschenrechte westlich? (Munich: Kössel Verlag, 2015).

36 In successive chapters, I draw from Ricœur's general textual hermeneutics, his narrative hermeneutics, his hermeneutics of human capabilities and aspects of his social philosophy. Then I draw from his early texts on decolonization, the question of symbolics in Course of Recognition and finally again the more political side of human capabilities. In each case, I critique him and develop my own views on the technical dimension of language utterances, the hermeneutics of human-technology relations, incapabilities, organizationized action and the broader social theoretic framework. Finally, unlike in Western philosophy, violent action and the difficulties of protest strategies are thematized. 
velopment is my own. A synthetic view of this development is given in the Conclusion.

Third, in the "Intermediary reflection" and the "Conclusion", I situate this study in respect of critical social theory. I assume a position of "simple exteriority", which suspends the task of ethical justification in order to focus on the most rigorous description possible. At the same time, in anticipation of possible critique (or "complex exteriority"), this study already provides the means for describing the stakes, ambiguities and paradoxes associated with the technicity of action. I therefore do not assume a position of a naïve value neutrality, let alone of value indifference, but propose a provisional suspension of critique in the light of the fact that, in this study, I do not dispose of the means by which to provide ethical commitments with justification. This theoretical position is "hermeneutic", without being Ricœur's position. ${ }^{37}$

These three points of divergence warrant my characterisation of this book using the general adjective "interpretative" or "hermeneutic" (rather than the narrower "Ricœurian").

Now the time has come do have a closer look at the steps by which the argument of the book is constructed. The objectives of this study required dividing the book into two parts. Part 1 concentrates on the two major components of the technicity of action, namely acquired capabilities and means of action. Part 2 examines the relation between the technicity of action and the urgency imposed on action by ethical and political concerns (see $\S 5$ ).

\subsection{Part 1: The Technicity of Action: Capabilities and Means}

The first part consists of a gradual accumulation of insights on the coordination of human capabilities and means of action. The argument fans out between the technicity of the simplest forms of communication and interaction, and the broadest social theoretical overview of collective action and institutions.

The aim of Chapter 1, "The Effectiveness of Symbols: Mediology and Hermeneutics”, is to outline the specificity of a hermeneutic approach to action and to dismiss the still recurrent notion that hermeneutics is exclusively at home in textual practices. To advance my case, I take up a debate with Régis Debray, who gives a scholarly articulation of the view I reject and offers an attractive alterna-

37 I assume this theoretical stance, drawing on Luc Boltanski, On Critique: A Sociology of Emancipation, trans. Gregory Elliot (Cambridge: Polity, 2011) and do not engage here with Ricœur's intervention on the relation between hermeneutics and a critique of ideology in From Text to Action. 
tive to it. Debray developed a field of study called mediology. Although he argues in favour of a demarcation of this field from other social sciences, such as semiology, sociology, history and communication theory, he often treats hermeneutics with some hostility. This chapter advances a more accurate understanding of the relationship between mediology and hermeneutics by focusing on symbolic efficacy. Three areas of converged interest are identified and discussed: (1) the mutual implication of the technical milieu and the world of technology, (2) the process of autonomisation and re-appropriation of media or texts, and (3) vigilance in politics.

The aim of exploring these convergences is not to sidestep the differences, but rather to make of my erstwhile opponent an ally to help me make the case for a hermeneutic approach to the technical dimension of action. This strategy requires this chapter to demonstrate how Ricœur understands the transition from theorizing text to theorizing action ("from text to action", as a volume of his essays is called). In fact, From Text to Action serves as a guide providing a first entry into a hermeneutic approach to action, and more specifically to the place of capabilities and means in interaction. This provisional overview is explicitly elaborated in Chapter 2.

Under the title "Habitus - Means - Worldliness," Chapter $\mathbf{2}$ takes over the general anthropological perspective on human action from Chapter 1 and theorizes the fact that action is mediated. The mediation of action is described as essential to human reality. However, this fact takes on different forms in different times and places. In critical engagement with Norbert Elias, I describe hominization as the collection of "civilizing processes" by which people of different cultures in different times and places are formed. This happens through the changing combination of three interdependent anthropogenetic components: society, signs and technics.

The manner in which the third of these components, technics, is constitutive of all cultural events deserves special attention. I argue that action, and more specifically, its technical dimension, consists of three interdependent elements: habitus (capability or technical disposition), instruments (the system of technical objects) and worldliness (the understanding interaction with people's social and material environment). The changing interrelation of these elements through a structural sequence of prefiguration, configuration and refiguration describes a hermeneutics of action, comparable to the hermeneutic structure of narrativity demonstrated by Ricœur. As such, the technical dimension of action is an aspect of all civilizing processes: not only is all culture dependent on the technical means of its existence, but all technical events, by virtue of their instrumentality, carry meaning, transmit, and humanize (in the sense of contributing to the form of human existence). Consequently, any experience by which people must nego- 
tiate cultural difference presupposes and depends on the threefold technical dimension of interaction. Each instance of such negotiation amounts to an intervention in the processes of civilization. The self-reflective potential of such interventions can be theorized as part of the problem of symbolic efficacy (cf. Chapter 1).

The complex of habitus, means and worldliness examined in Chapter 2 is further explored in Chapter 3 under the title "Human Capabilities in the Light of Incapabilities”. In this chapter, most is made of the central term of Ricœur's later philosophy, capability, but I fill in the gap left largely unfilled by Ricœur - a theorizing on incapability.

Let us examine this in more detail. Central to Ricœur's later hermeneutics of the self is the "I can". While he explores the range of capabilities, the notion of capability itself nevertheless remains underdetermined from what one may call the "technical" point of view (in the sense I developed in the first two chapters). In this chapter, I defend the claim that the hermeneutics of the capable human being requires a development of its technical dimension, in other words, a reflection on the skills and means related to the "I can". To support this claim and to assert that incapability is the practical horizon of the action of the capable human being, I examine five dimensions of incapability. Subsequently, the tension between ability and inability is described as the originary finitude of the human agent. This conclusion makes it possible to demonstrate that the capable-incapable human being reveals the technicity of the human being over the entire range of his/her social interactions.

In the action theoretic framework deployed in Ricœur's later philosophy (as dealt with in Chapter 3), acting agents reveal their capabilities when these are activated in interaction, face-to-face with others and through institutional mediation. Between these extremes of personal and anonymous interaction, there remains an intermediate form of human interaction that cannot simply be described as either personal or anonymous, namely organized, collective action. This is already a problem for Ricœur's action theory, however, in the light of the later chapters of the book, we will gain a better sense of the significance that this has for a sociological and political understanding of collective action. This shortcoming in Ricœur's action theory is dealt with in Chapter 4, "Organized Action: Agency, (In)capabilities and Means”.

While I recognize the absence of a thoroughly systematic treatment of this question by Ricœur, I argue that his work nevertheless contains a number of passages in which valuable insights into the phenomenon of organized action are given. This is demonstrated by an analysis of five relevant parts of his work: first, the notion of institution from Oneself as Another, and, second, in the same book, the notion of practices as adopted from MacIntyre, third, the idea 
of an advisory team as used now and then in Ricœur's reflections on medical ethics, fourth, the theorizing of the representation of social collectivities under the term "participative belonging" (appartenance participative) in Time and Narrative 1, and fifth, the hermeneutics of "social capabilities" in The Course of Recognition. What is at stake in exploring these five passages lies not only in doing them justice in their quite divergent contexts, but also in testing the possibility of a synthesis of these insights.

The constructive part of this chapter consists in transposing the categories of capability and incapability already developed in Chapter 3 to the agency of groups or organizations. Some of the same complexities are to be found in the case of the group action.

By the time we arrive at Chapter 5, the reader should possess a good view of Ricœur's action theory and the way in which I have elaborated it with a focus on the technicity of action. It is then time to situate Ricœur in the broader field of sociological action theory. I do so by means of a comparison of key notions from Ricœur's work with those of Anthony Giddens's theory of structuration. Hence the title of the chapter: "The Hermeneutics of Human Capabilities and the Theory of Structuration". The aim of this chapter is to consolidate the work of the first four chapters and to suggest a number of points at which Giddens's early theoretic project could be used to strengthen and elaborate the theoretical construction assembled thus far.

This chapter, then, is set up as a dialogue between Ricœur and Giddens, in particular between the hermeneutics of the capable human and the theory of structuration. The chapter starts with an exploration of the key concepts on the basis of which to compare the two authors' views on the relation between actors and systems. On Ricœur's side, I comment on the concepts of institution and practice, and on Giddens's, I examine notions selected to present the "duality of structure". In the course of this exploration, four tasks are identified by which to refine the social theory of Ricœur's Oneself as Another: first, surpassing its ultimately teleological schema of action, second, exploring the stabilisation of action despite the uncertainty attributed to the teleological schema, third, reinvesting the notion of constraint, and fourth, clarifying the ambiguity in the notion of institution. In the chapter's conclusion, the contribution of a Ricœur-Giddens dialogue to the accomplishment of these four tasks is demonstrated.

In all this action theorizing, two crucial elements are still lacking. The first is the complex composition of compromises in action by agents in the heat of the action. Then, this theorizing makes quite general anthropological claims (as I pointed out from the beginning) and for this reason we would do well to confront this mode of thinking with the second crucial missing element, which is experienced from outside of the "default" academic orientation to the West. Both of 
these points can be dealt with simultaneously. To clarify the way I have chosen to deal with these matters, I need to return to the example evoked at the beginning of this introduction: protest action.

\section{The Heat of Action}

Looking back on the wide range of social movements world-wide since the Arab Spring of 2011, Bertrand Badie tries to capture the historical novelty of these events as "globalization, act 2".38 One could indeed consider these events from a macro perspective and comment on the increasing integration even of marginalized peoples in course of historical events on a global scale, the interdependence of societies and the mobility of masses of individuals. This is what Badie does when he describes the broad tendency of society to become more powerful than politics. But the same author could equally consider these movements on a micro perspective. Here he is struck by the fact that they are "constituted by an infinite number of micro strategies and distinct social behaviours are aggregated". ${ }^{39}$ This alternative understanding opens by taking a different point of view, the one I also adopt in the last two chapters of this book.

Looking more closely, one observes that with all the significant changes of global politics and the living conditions of local societies, a number of persistent aspects of these micro strategies remain. In fact, these aspects are so persistent that one finds them in social movements and political contestations throughout human history. This dimension of the composition of capabilities and means, of the technical dimension of action with ethical concerns - a difficulty which all people have to face in all spheres of life - has been explored in Part 1 of this book. In Part 2, I continue this exploration, with the "heat of action", dramatically presented in contemporary social movements, as a magnifying glass. Indeed, the question of extreme means - the recourse to violence - gives us a singular view on the complex composition of action and brings the dramatic role of ethical considerations in action to the fore better.

38 Bertrand Badie, "L'acte II de la mondialisation a commencé," interview with Marc Semo, Le monde, 8 November 2019, https://www.lemonde.fr/idees/article/2019/11/08/bertrand-badie-lacte-ii-de-la-mondialisation-a-commence_6018418_3232.html, last accessed 5 February 2021. The theses advanced in this interview fit into Badie's broader perspective on international politics as developed in a series of recent books, for instance, L'hégémonie contestée. Les nouvelles formes de domination internationale (Paris: Odile Jacob, 2019).

39 My translation. 
I am certainly not the first philosopher to be drawn into protest movements with an action theoretical interest. To name but two examples, half a century ago Hannah Arendt and Jürgen Habermas both developed some of their most important political philosophical ideas in confrontation with protest movements. Considering the student protests, the anti-racist movements and the anti-war movement in the United States in the late 1960s, Arendt ${ }^{40}$ distinguishes the essence of power as generated when many people "act in concert", rather than from the deployment of powerful instruments and arms. In his long view of human history, Habermas ${ }^{41}$ describes the social mutations of, and changing relation between, two forms of human rationality and their corresponding forms of action: one instrumental, the other communicative. The instrumental reason focuses so intently on the means by which to realize pre-set aims that it marginalizes the agreement-seeking and value-affirming practices of communicative reason. While Marx set his hope on the proletariat as the force of liberation from the strictures of capitalism, Habermas set his hope on the student movement of the late 1960s to rejuvenate and energize the social, indeed the political, exercise of communicative action.

In my studies, I am quite close to Arendt and Habermas in adopting an action theoretical view on these events. I also embrace the way in which they hold on to philosophical reflection and social science, in such a way that their conceptual developments remain dialectically bound back to the detail of real historical events. However, I do not follow them in their action typologies, ${ }^{42}$ which undermine the description of action, as these distinctions can be quite difficult to maintain in analysing cases in detail.

To get a still closer view on what I propose, let us consider a more recent example of philosophical commentary on particular events. I am thinking of the way in which Habermas and Jacques Derrida reflected on the terror attacks in the USA in September 2001. ${ }^{43}$ These attacks are, of course, not initiatives of social movements, but in so far as they are attempts to coordinate strategic considerations and normative aspirations, the philosophers' responses to it are, for

40 Hannah Arendt, “On Violence,” in Crises of the Republic: Lying in Politics, Civil Disobedience, on Violence, Thoughts on Politics and Revolution (San Diego, CA: Harvest/Harcourt Brace Jovanovich, 1972), 134-84.

41 Jürgen Habermas, “Technology and Science as 'Ideology”' [1968], in Toward a Rational Society: Student Protest, Science, and Politics (London: Heinemann, 1972), 81-121.

42 As I have already argued, inspired by Hans Joas, in Ernst Wolff, “'Technology” as the Critical Social Theory of Human Technicity," Journal of Philosophical Research 41 (2016): 333-69.

43 Giovanna Borradori. Philosophy in a Time of Terror: Dialogues with Jürgen Habermas and Jacques Derrida (Chicago, IL: University of Chicago Press, 2003). 
my purposes, instructive. In a true philosophical fashion, both strive for maximum understanding of the perpetrators while condemning the acts perpetrated. This is the first interesting point: in order to understand these initiatives, one has to situate them in the broader historical context of international power relations and institutionalized violence. Moreover, such a critical view on the long-term events calls for a self-critical view on the West in its relations to its "others". Thus they perform a hermeneutic gesture, which always forms the backdrop to my own contribution.

However, there is a second significant dimension of these interviews. In their respective philosophical ways, they confirm that these events compelled the West - and in particular, those who work with its intellectual heritage - to scrutinise this heritage in the most energetically self-critical way. In this sense, the arguments of both are in continuity with the spirit of the Enlightenment. Moreover, both attach to this self-critique the need for open discussion with the cultural other; Habermas does so directly, ${ }^{44}$ whereas Derrida does so by critiquing a lack of dialogue. ${ }^{45}$ Self-critique, they argue, requires encountering the other. And yet, remarkably, they both immediately proceed by evading this task. ${ }^{46}$ This performative contradiction is as glaring as it is puzzling. This is, in any case, the negative lesson I derive from them.

When, in the last chapters of this book, I turn to acts of political contestation, my aim is not to offer an encompassing political or political philosophical schema for interpreting such events. Rather, in continuity with the first five chapters of the book, I consider such events bearing in mind the four action theoretical questions mentioned above in $\S 1$. In line with the authors I have cited, I attempt to expand and refine my theoretical understanding in a close dialectical loop with concrete historical events. For this purpose, I examine suggestive examples, rather than document general tendencies. I am not asking the historical question of contextualisation, nor a sociological question in the sense of identifying factors contributing to certain forms of movements. Nor am I asking a political scientific or legal question (although, corresponding with the design of my project, significant points from these disciplines are dialectically bound up in this project). Rather, my focus is the action theoretic and hermeneutic question as to the way in which such actions take shape as meaningful for agents in their interaction and in their confrontation with particular contexts.

44 Jürgen Habermas and Giovanna Borradori, "Fundamentalism and Terror - A Dialogue with Jürgen Habermas" in Borradori, Philosophy in a Time of Terror, 25-43, here $36 \mathrm{ff}$.

45 Jacques Derrida and Giovanna Borradori, "Autoimmunity: Real and Symbolic Suicides - A Dialogue with Jacques Derrida,” in Borradori, Philosophy, 85-136, here $121 \mathrm{f}$.

46 The interviewer did not seem to notice this either. 
At the same time, as I have pointed out from the outset, action theoretical claims have a general anthropological reach. And since this is the case, I do my best to avoid Habermas's and Derrida's performative contradiction. On the contrary, I hope to illustrate the value of at least some openness to authors and actors who are not part of the Western philosophical "library". ${ }^{47}$ When Habermas and Derrida claimed the need for such intercultural openness, it was not because of naïve exoticism, and I do not succumb to naïve exoticism when I apply the lesson they forgot. Furthermore, if, as I have claimed from the outset, action theoretical claims have a general anthropological reach, then the openness to the cultural other is a first step in precautionary self-relativisation.

\subsection{Part 2: Finding Compromises in Practice}

The second part of this book consists of three studies. As in the first five chapters, Ricœur is my main interlocutor, serving sometimes as a partner and sometimes as an adversary in advancing my reflection.

In the centre position I place not a philosopher, but an agent, someone who has had to traverse and negotiate the difficulties and complexities of going over to action. I submit to scrutiny a self-interpretation that Nelson Mandela wrote on his own turning to action. What can we learn from Mandela, from the period of peaceful protest, but even more from his decision to adopt violent strategies? Hence the title of Chapter 7: "Acts of Violence as Political Competence? From Ricœur to Mandela and Back”.

In the third section of his The Course of Recognition, Ricœur famously engaged in a debate with Axel Honneth's Struggle for Recognition. ${ }^{48}$ A careful reading of the debate shows how Ricœur subscribes to Honneth's understanding of struggles for recognition, even to the point of integrating it into Ricœur's own political philosophical. However, he argues for the possibility of exceptional, ephemeral experiences of truce in such struggles. These "states of peace" provide a special vantage point from which to grasp the meaning and aims of polit-

47 I use the term in the sense in which Mudimbe speaks of the colonial "library" in The Invention of Africa, 175, 181.

48 Axel Honneth, Kampf um Anerkennung: Zur moralischen Grammatik sozialer Konflikte (Frankfurt am Main: Suhrkamp, [1992] 1994) / Axel Honneth, The Struggle for Recognition: The Moral Grammar of Social Conflicts (Cambridge: Polity Press, 1995). 
ical struggles. Following Luc Boltanski, ${ }^{49}$ Ricœur sees acts of radical love (agapé) as a category of social action which reveals the logic of a "state of peace"; for Ricœur, Willy Brandt's genuflection in Warsaw on 7 December 1970 serves as a paradigmatic example.

In scholarship on The Course of Recognition, the question regarding which traits of "states of peace" qualify them to provide this exceptional perspective on political struggles has not received sufficient attention. A systematic examination reveals a startling theoretic possibility that is not entertained by Ricœur, namely that their major characteristics (particularly the fact that they are based on a logic of non-equivalence) may be shared by another family of actions. In his book Love and Justice as Competences (in the same sections from which Ricœur draws insights on agapé as category of social action), Luc Boltanski argues that certain acts of violence also remain true to a logic of non-equivalence.

In Chapter 7, I do not examine the entire range of violent acts. Rather, the focus is be on one particular kind: violent acts of resistance against institutionalized violence. Insights on the way in which such acts are to be understood are drawn from Nelson Mandela's speech at the Rivonia trial. I argue that Mandela's gradient strategy of ways of "answering violence with violence” provides us with suggestions on how to expand Ricœur's phenomenology of ways by which political struggles for recognition may be legitimately interrupted and by which insight into these political struggles may be gained.

In this central chapter of Part 2, I am careful to avoid viewing Mandela as a political icon, one, perhaps, without comparison, and to zoom in on him instead as agent. My objective is to maintain this focus when considering the action possibilities and dilemmas of those citizens of the same country who, half a century later, are faced with similar problems, even though they are no longer in a pariah state, but what has been hailed as a model democracy instead. Unsung, ambiguous agents, like those referred to by Badie, whose faces we may see for (at most) a split moment on the daily news programmes. I learn from some of these people in Chapter 8, "Justice Despite Institutions. Struggling for a Good Life from the Destitute Edge of Society.”

Continuing the previous chapter's exploration of Ricœur's relevance for political protest and contestation, Chapter 8 aims to clarify the pursuit of justice by people who live at the very edge of society, on the brink of utter destitution. We

49 Luc Boltanski, L'amour et la justice comme compétences. Trois essais de sociologie de l'action (Paris: Métaillé, 1990) / Love and Justice as Competences. Three Essays on the Sociology of Action, trans. Catherine Porter (Cambridge: Polity Press, 2012). 
are still pursuing the core objective of this book, namely theorizing the limited capabilities of people and the means by which they interact.

The chapter starts with an exploration of the place of conflict and violence in Ricœur's political philosophy as framed by his later hermeneutic anthropology. I argue that Ricœur assigns a major role to conflict in his political thought. But conflict is not always violence, and it is important to see exactly how he demarcates the place of violence within "the political."

Subsequently, I pursue my line of enquiry with an excursion through labour sociology written in Johannesburg during the last decade or so. The rationale for this inclusion is twofold: these empirical studies help us to retain the practical philosophical thrust that Ricœur's hermeneutics calls for, and they help to question Ricœur's strange limitation of reflection on conflict (in the context of a general hermeneutic anthropology) to a debate in Western democracies. I reject the unspoken assumption - still so prevalent in political philosophy - that one can sufficiently think through something as broad as democracy by focusing on Western examples alone. One positive consequence of my other-than-Western orientation is that this provides a much better vantage on the pursuit of justice from the miserable edge of social co-existence. Accordingly, I can present and reflect on "violent democracy", which provides the background necessary to introduce a distinction between violence relatively close to the centres of privilege, and violence closer to the precipice of destitution. I explore two ways of pursuing the aim of justice from this "edge", the first responding to injustice by means of violent action, and the second responding by contestation, closer to the peaceful possibilities of democracy. In violent democracies, it is impossible to understand one without the other. They are both ambiguous attempts at prudent ${ }^{50}$ strategies to improve justice where institutions are failing people. Each is defined in relation to the other, and for each the other remains a viable alternative.

Finally, a number of conclusions are drawn regarding the value of this segue for the attestation by capable and suffering humans of their ability to act and to pursue justice. This will also have implications for those whose profession requires thinking about this quest for justice in the second order of theory or philosophy.

But I have been in academia too long to ignore the scepticism which still often greets attention to "African" events. Anticipation of this scepticism, in Chapter 6 (the first chapter of Part 2) serves as a justification of my approach. Correspondingly, it is entitled: “Of What is 'Ricœur' the Name? Or, Philosophis-

50 The very specific sense of "prudence" used throughout this book is explained in Chapter 8, $\S 1$. 
ing at the Edge”. In that chapter, I demonstrate how natural it is to look for help and derive a number of insights from Ricœur, in thinking for and about a plural globalised world. Also (while remaining alert to the pitfalls of a simplistic, moralistic view on dialogue between civilizations), I demonstrate how a careful reading of Ricœur's hermeneutics indicates the necessity of listening to others, a project which he himself cannot complete. Once this has been established, the deployment of his hermeneutics of human capabilities in the second and third studies of Part 2 comes quite naturally.

Philosophising, we may recall, is also a practice. In this chapter I wish to contribute to the conflict of interpretations of Ricœur's work. Taking his early anti-colonial tract as a point of departure, I trace two lines of development in his thought: I start with his geopolitics for the post-independence world and then move on to his cultural critical view on modernity as revealed by decolonization. I highlight the significance of these two lines of thought for understanding Ricœur's hermeneutics as a response to disillusioned modernity. A vital implication of this view on Ricœur's work is that it requires completion by the cultural and geopolitical other. ${ }^{51}$ I offer an illustration of how such an intercultural philosophical debate could be reconstructed, taking Okolo Okonda as an exemplary partner in debate.

The political nature of philosophising is explored by showing how it can be motivated by the fate of people living "at the edge" of society, demonstrating how Ricœur's own philosophy is invigorated by political concerns, and insisting on the political implications of Eurocentric theorizing. The last three chapters of the book attempt - apart from their stated objective - to experiment with ways by which to oppose such Eurocentric theorizing in ways that brings theoretical rewards.

\section{Intermediary Reflexion and Conclusion: Towards an Integrated Theory of the Technicity of Action}

The contribution of this book consists of the insights documented in its various chapters, but the Conclusion serves a better purpose than mere compliance with convention. Together with the Introduction and the "Intermediary Reflection" be-

51 Taking Ricœur's philosophy as point of departure, the openness is to African events and scholarship. How valuable such reconstructed dialogues may be is demonstrated in Ernst Wolff, Lire Ricœur depuis la périphérie. Décolonisation, modernité, herméneutique (forthcoming). Note that my own point of departure is neither simply Western nor simply African. 
tween Part 1 and Part 2, the Conclusion looks more directly at the project as a whole.

One of my points of departure is the fact that action has meaning to the people who engage in action. The limited perspective on the technicity of action changes nothing regarding this fact - quite the contrary. I demonstrate how the capabilities and means of action are simply part of the meaningful fibre of action. Furthermore, at numerous places in the book I show how the central concern of technicity, namely efficacy, remains in relations of mutual implication with the normative or ethical aspects of action.

A first important consequence of the fact that action is thus composed of divergent aspects is that it justifies the circumscribed view I adopt on one aspect, its technicity, in this book. However, this limitation comes at a price: every such focus on one aspect of action has to account for its integration with other dimensions of action. While I am cognizant of this challenge, it has to be borne in mind that the intellectual means appropriate to this examination of the technicity of action cannot give a full view on other aspects, here notably the ethical aspect. This second important consequence of the composition of action is responsible for the fact that, in this book, I do not engage with the meta-ethical philosophising required to clarify the ethical dimension of action in isolation. This means that I have to adopt a descriptive view on action and renounce the ambition of developing it into a full critical theory of the technicity of action. I give an outline of this position in the form of an "Intermediary Reflection", which forms the hinge between Part 1 and Part 2 of the book. The precise nature of the point of view from where I write - the limitation of the promise of what this book could be - informs the Conclusion too.

After developing my views on the technicity of action in a constant debate with Ricœur and contributors from the social sciences throughout the book, it seems useful to let those debates recede into the background in order to provide a retrospective view on the gains of these labours. The first aim of the Conclusion is to give a synthetic view of the technicity of action, not to replace the detailed exploration throughout the book.

Then, this brief synthesis again brings to the fore the entanglement of technicity and ethnicity of action, a second point to which I come back in the Conclusion.

This allows me, finally, to advance a hypothesis (which silently forms throughout the book) on responsibility. This hypothesis is that responsibility is best understood as part of the technicity of action, more specifically as the technical dimension of ethical and political action - action which can and should never be reduced to the technical dimension. The preceding chapters allow me to consider reflection on responsibility as grappling with the question: how do 
we, situated as we are in socio-historical reality, realize our ethical aims (whatever they may be) in full awareness of the difficulties of action? Considered in this way, responsibility is open to the question of the justifiable ethical views, without being the meta-ethical justification of any ethical value or concern. Understood in this way, responsibility would be the opposite of moralism, in two ways: it takes into account the context and difficulties of action and efficiency; and it assumes a hermeneutic (that is, a perspectival, context-determined) view on its own normative concerns. To put it another way: responsibility is the middle way between moralism and cynical realism (something is at stake in action, and the mere pursuit of efficiency of will is a reductive way to view this).

In this way, the Conclusion refers back, albeit obliquely, to Max Weber, who has already been invoked in this Introduction. A century ago, Weber grappled with the dilemma of the irreconcilable opposition of an ethics of responsibility and an ethics of conviction. My book is certainly an attempt to contribute something to our understanding of this dilemma, but on my own terms. Exploring the difficulties of giving a sophisticated descriptive account of the technical dimension of human action, in view of the practical dilemmas of finding compromises between normative and strategic considerations in action, aims at achieving this. 
